\title{
The Soil-Land use System in a Sand Spit Area in the Semi-Arid Coastal Savanna Region of Ghana - Development, Sustainability and Threats
}

\author{
T. W. Awadzi. ${ }^{*}$, E. Ahiabor ${ }^{2}$ and H. Breuning-Madsen ${ }^{3}$ \\ ${ }^{1}$ Department of Geography and Resource, University of Ghana, Legon \\ ${ }^{2}$ Savanna Agricultural Research Institute, Nyankpala \\ ${ }^{3}$ Institute of Geography, University of Copenhagen \\ *Corresponding author
}

\begin{abstract}
The development and sustainability of a horticultural system at the Keta sand spit in south-eastern Ghana is described and discussed. The main crop is shallot grown on pure sandy soils in a semi-arid climate. It is a cash crop system highly dependent on a substantial input of manure and irrigation water from a shallow aquifer. The investigation comprises soil profile descriptions and analyses on the dominant soil type on the sand spit, measurement of electrical conductivity of well water and in the soil, crop experiments and interviews of farmers for local knowledge. The findings show that the farmers have developed a very intensive horticulture system on soils with low nutrient contents and low water holding capacity, and in a climate with a long drought period and a short period of about 3 months where percolation takes place recharging the fresh water lens.
\end{abstract}

\section{Introduction}

In the south-eastern corner of Ghana the River Volta enters the Atlantic Ocean forming a large delta. The landscape east of the Volta's outlet consists of a big shallow lagoon, named the Keta Lagoon, surrounded by marshy areas with few elongated sandbars, probably old levees. Facing the Atlantic Ocean and separating it from the Keta Lagoon, a large sandbar had developed. Formerly, the people of this area were mainly fishermen and grew a few vegetables for domestic consumption. Although the arrival of the Europeans boosted the economic activity it did not affect the soil-land use system for centuries, except for the introduction of coconut production. But in the 1930's world economic depression, the collapse of the coconut production due to the Cape St Paul disease, and the rapidly increasing population forced the people to give up the old agricultural systems and develop intensive horticulture based on shallot production.

The system is highly dependent on the application of organic manure and irrigation, the latter because of the semi-arid climate of the region. Since the 1930's, the population has increased drastically and the people were then forced to expand their agricultural activity and crop more land. Further expansion is limited due to competition with housing. This increase in population and farmland had increased the consumption of water, and it is today a question of whether the fresh water aquifer in the future can provide the water needed for domestic use as well as for irrigation.

Shallot cultivation is a cash crop system highly dependent on a substantial input of manure and irrigation water from a shallow aquifer. The manure is mainly cow dung and poultry droppings bought up to $100 \mathrm{~km}$ away from the Keta sand spit. There are three shallot growing seasons, one is totally rain-fed, another is partly rain-fed while the last one in the dry season is totally dependent on irrigation, normally done by well water. The yield varies between the three seasons. The yield is only about two-thirds in the irrigation seasons compared to the rain-fed seasons. This is probably due to a slight salinisation of the soil due to an irrigation scheme that only re-wets the upper $10 \mathrm{~cm}$ of the soil. Presently, electric pumping systems make sprinkler irrigation possible and the higher part of sand spit has been available for shallot production. This is a severe threat to the sustainability of the farming systems as the recharge of the fresh water lens might not be adequate, and the fresh water lens will deplete and salt water intrusion might occur.

West African Journal of Applied Ecology - Volume 13 
Interviews of farmers showed that competition with other areas growing shallots is keen and the profit margin is low. If the economic returns by shallot production are not increasing for it to compete with other producers, the system will turn into a pepper-okro-tomato horticultural system, as it is already happening at present. But in the future environmental problems like depletion of the fresh water aquifer and pollution of the aquifer by pesticides and nutrients might change the farming system drastically. Quota on water used for irrigation might be introduced as well as limits for the use of manure. This will change the agricultural system drastically and it is a question whether it can survive as a horticulture system in its present form.

The paper describes the evolution of the shallot agricultural system on the Keta sand spit, and discusses its sustainability. The description is based on archival studies of the past, on indigenous knowledge on shallot farming of today given by one of the authors, who has lived most of his life in the area, and on agronomic experiments and records carried out on nine sand beds. The soils were described and analysed, the quality of irrigation water and soil water were measured, and a quantification of seed used for planting, manure used on the sand beds and the yields of shallots were carried out.

\section{Study area}

\section{Materials and methods}

Fig. 1 shows the location of the study area in the south-eastern corner of Ghana (lat. $5^{\circ} 45^{\prime} \mathrm{N}$ to $5^{\circ} 53^{\prime} \mathrm{N}$, long. $0^{\circ} 40^{\prime} \mathrm{E}$ to $\left.1^{\circ} 00^{\prime} \mathrm{E}\right)$. It is part of the Ho-Keta plain that forms an area of low relief, gradually sloping towards the south, ending in the Keta Lagoon and the Keta sand spit at the Atlantic Ocean.

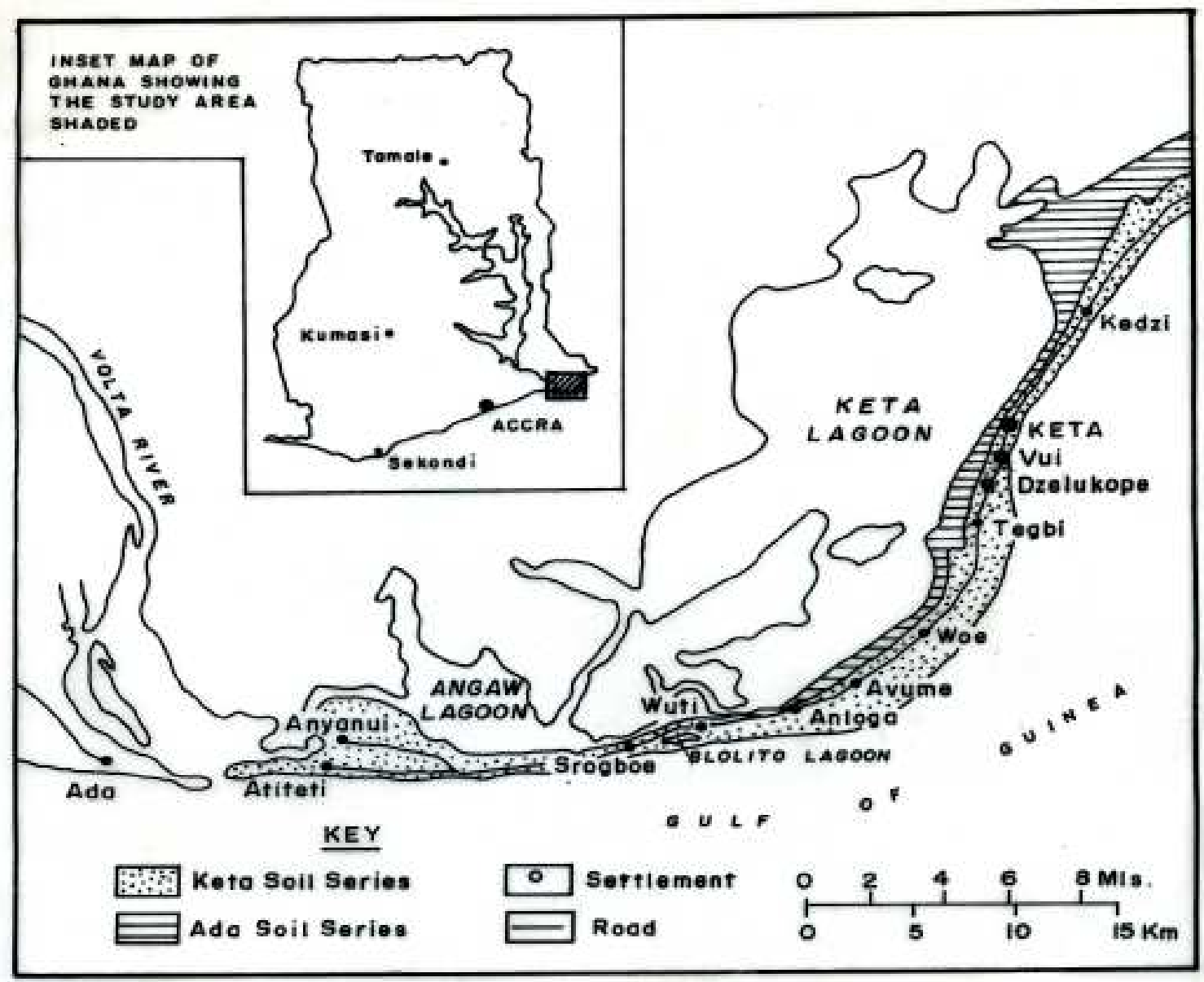

West African Journal of Applied Ecology - Volume 13 
Fig. 1. Location of the study area

The Keta Lagoon covering about $300 \mathrm{~km}^{2}$ is believed to be part of the former Delta of River Volta and large areas surrounding the lagoon are liable to flooding. It is a shallow lagoon rarely deeper than $2 \mathrm{~m}$. The water is brackish with varying seasonal salt contents, averaging 18.7 PSU (Sorensen et al., 2003; Anon., 1993). The geology, favouring rapid underground discharge in the catchment area of the lagoon, and the semi-arid climate make the fresh water input to the lagoon very low, and the Todzi stream is the only big stream that flows into the lagoon. Although there is an input of fresh water to the lagoon, the water level varies more than $1 \mathrm{~m}$ during the year, and the surrounding marshy areas are seasonally flooded.

South and east of the Lagoon, the Keta sand spit has developed, separating the lagoon from the sea. It is narrow sand spit approximately $27 \mathrm{~km}$ in length and barely $2 \mathrm{~km}$ at its widest portion. It consists of white medium marine sand forming narrow elongated sandbars with narrow depressions in between. Between the sand spit and the lagoon, a discontinuous narrow strip of marshland exists broadest toward the west.

According to Dickson \& Benneh (1995), the climate is Dry Equatorial. Temperatures in the study area are quite high with a mean monthly temperature of about $30^{\circ} \mathrm{C}$ in the warmest month, March, and about $26{ }^{\circ} \mathrm{C}$ in the coldest month, August (Dickson \& Benneh, 1995). The average minimum diurnal temperature is about $25^{\circ} \mathrm{C}$ and the average maximum is about $33^{\circ} \mathrm{C}$. Frost never occurs. Average annual rainfall is below $900 \mathrm{~mm}$ (Dickson \& Benneh, 1995) with an uneven distribution over the year (Fig. 2). From November to February the Harmattan dominates with winds from northeast and gives rise to a long dry season. 


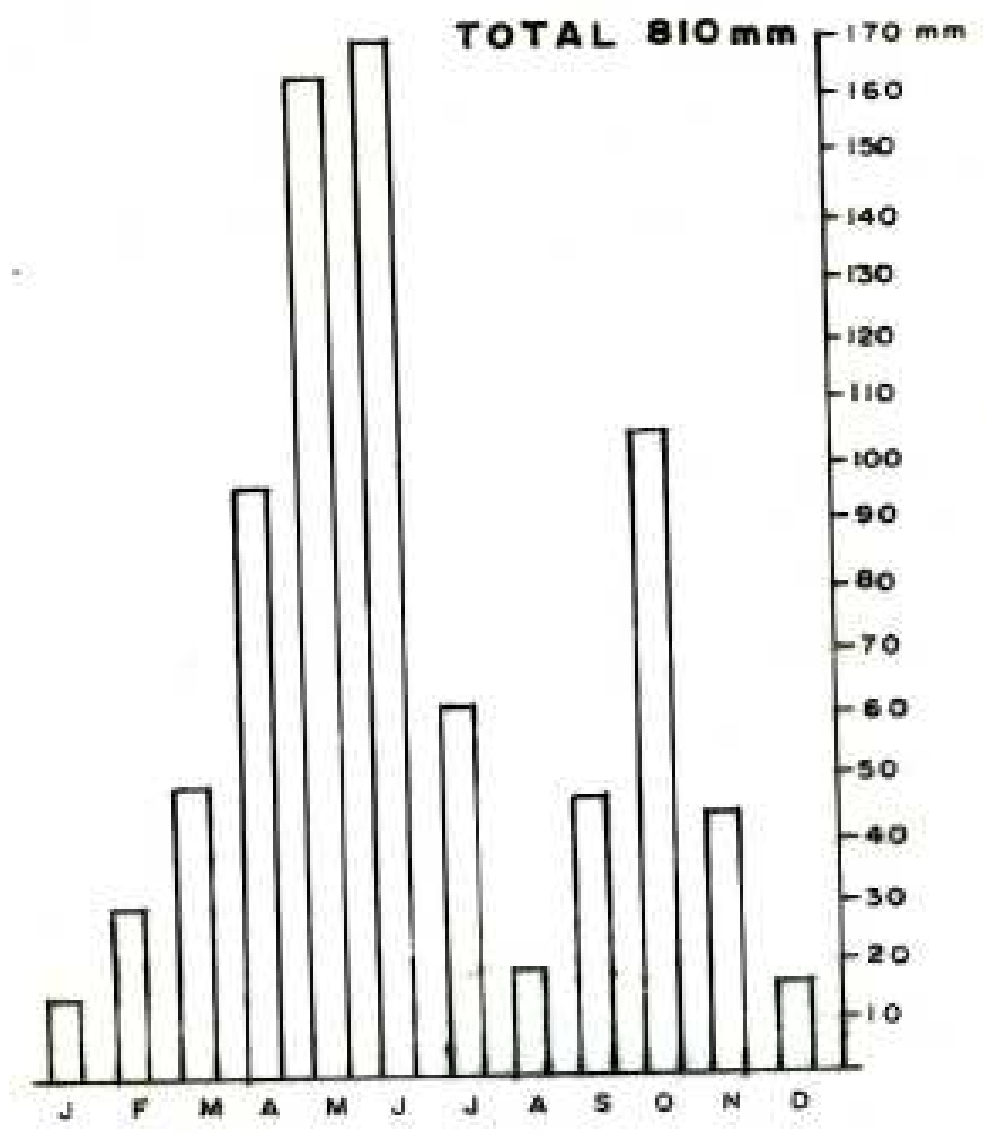

Fig. 2. Mean monthly average rainfall in the study area Source: Jeppesen (1971)

From March, the winds blow from southwest and the monthly precipitation increases and reaches a peak between April, May and June, the major rainy season. In July and especially in August the precipitation is very low representing the minor dry season. September to November is the minor rainy season, which often is not reliable. The rain falls mainly in few heavy showers. As these showers are erratic and unreliable, the year-to-year pattern of the peak rainy season fluctuates as well as the total rainfall. In some years, the peak rainy season starts as early as March, and in other years it starts in June. The annual total rainfall varies, from about $400 \mathrm{~mm}$ in some years to more than $1200 \mathrm{~mm}$ in others.

The annual potential evapotranspiration is estimated based on Christensen \& Awadzi (2000) to be about $1500 \mathrm{~mm}$, evenly distributed over the year, and the monthly evapotranspiration varies between 100 $\mathrm{mm}$ and $150 \mathrm{~mm}$. From an agricultural point of view the temperature per se does not exert a major constraint on agriculture, but that is definitely the case for the low and erratic rainfall, which does not allow more than one rain fed growth season per year.

There are two major soils in the area. These are the Ada soil series representing the marsh areas and the Keta soil series representing the sand bars (Asiamah, 1995). According to Asiamah (1995), the Ada series is clayey or heavily clayey, slightly acid and extremely mottled. They are according to WRBsystem (ISSS/ISRIC/FAO, 1998) a Solonet, and according to Soil Taxonomy (Soil Survey Staff, 1998), a Natraqualf. They occupy the greater part of the flat, poorly drained areas adjoining the Keta Lagoon. The Keta soil series occupies the scattered sandbars in the marsh area and the large narrow Keta sand spit along the coast. Due to the sandy texture they are, according to the ISSS/ISRIC/FAO (1998), Arenosols and according to Soil Taxonomy, Psamments.

West African Journal of Applied Ecology - Volume 13 
The investigation comprises soil profile descriptions and analyses on the dominant soil type on the sand spit, measurent of electrical conductivity of well water, crop experiments and interviews of farmers for local knowledge. Three soil profile pits were dug, described and sampled horizon by horizon. However, for physical and chemical analysis one representative profile was selected. The soil samples were airdried and passed through a 2-mm sieve, and the content of gravel (> $2 \mathrm{~mm}$ ) by weight was determined. Particle size distribution was determined by sieving sand fractions and using the hydrometer method for determining the silt and clay fraction. Soil $p \mathrm{H}$ was determined potentiometrically in distilled water and $0.01 \mathrm{M} \mathrm{CaCl}_{2}$ at a soil-solution ratio of 1:2.5. Total carbon (C) was determined by dry combustion using an ELTRA CS 500. Total nitrogen (N) was determined by the Kjeldahl method. Total phosphorus (P) was determined spectrophotometrically by the molybdenum blue method using ascorbic acid as a reductant after heating the soil to $550{ }^{\circ} \mathrm{C}$ and extracting with $6 \mathrm{M}$ sulphuric acid. Electrical conductivity was measured on extracts from water saturated samples using a Metrohm conductometer E587.

Experiments on shallot production were carried out on nine farm beds from 1997 to 2001. Yields per square metre were determined at the end of the growing season. The quality of the irrigation water (electrical conductivity) was determined directly in the wells used for the irrigation by a Metrohm conductometer E587. Furthermore, during 1 year the electrical conductivity was measured in the soil at the time of harvest. Thirty farmers were interviewed concerning the various aspects of the shallot cultivation system and on sustainability.

Soils

\section{Results and discussion}

The Keta soil series occupies the scattered sandbars in the marsh area and the large narrow Keta sand spit along the coast. The sandbars in the marsh area are probably levees formed by the River Volta, while the large Keta sand spit has developed directly from marine sand deposits. Table 1 shows the physical and chemical data from the selected profile located at the sand spit. The Keta soil series is located at slightly higher levels than the Ada soil series and is, therefore, not flooded by brackish water from the lagoon. The soils are, therefore, not characterized by high salt contents, as salt is leached from the profiles during the rainy season. This is reflected in Table 1 by the low EC-values.

TABLE 1

Soil analytical data for a typical sand bed at Anloga, the Keta soil series

\begin{tabular}{|c|c|c|c|c|c|c|c|c|c|}
\hline Depth cm & $\mathrm{p} \mathrm{H} \mathrm{H}_{2} \mathrm{O}$ & $\mathrm{p} H C a$ & & $E C$ & $S / m$ & $C(t o t) \%$ & humus \% & $N(t o t) \%$ & $P(t o t) \%$ \\
\hline $0-5$ & 8.1 & 7.3 & & 0.65 & & 0.6 & 1.1 & 0.07 & 0.04 \\
\hline $5-30$ & 7.7 & 7.0 & & 0.25 & & 0.5 & 0.9 & 0.05 & 0.03 \\
\hline $30-50$ & 7.2 & 6.5 & & 0.25 & & 0.2 & 0.3 & 0.02 & 0.02 \\
\hline Depth cm & $<2 *$ & $2-20$ & 20 & & $63-125$ & $125-250$ & $250-500$ & $500-1000$ & $1000-2000$ \\
\hline $0-5$ & 3 & 4 & 1 & & 3 & 30 & 42 & 15 & 3 \\
\hline $5-30$ & 2 & 2 & 2 & & 2 & 24 & 45 & 20 & 3 \\
\hline $30-50$ & 1 & 1 & 1 & & 1 & 27 & 46 & 19 & 4 \\
\hline
\end{tabular}

- The texture classes are in microns, the figures in percent.

The sandy deposits are low in organic matter and clay content as also described by Purnell (1955) and Ahn (1970). The topsoil is shallow, only few cm thick. It is dark gray or dark brown due to a little humus staining. This horizon grades gradually into a loose pale brown to pale yellow sand. They are internally well-drained soils, but only to a shallow depth. Normally within 1-m depth, groundwater is found. Below

West African Journal of Applied Ecology - Volume 13 
the groundwater the soil might turn into dark grey or bluish sand or silt, with shells or shell fragments. At the Keta sand spit the shallow groundwater is not salty, unlike that found in the marsh area. It is a thin local freshwater lens superimposing salty groundwater. The groundwater lens is believed to originate from the precipitation surplus in the rainy seasons. Due to the high fresh water table, in times of heavy torrential rainfall, the soils in the depression become saturated, or even for a short period, covered by fresh water. However, in the dry season they become very dry and loose.

The plant nutrient content in the Keta soil series in its natural state is very low as sand particles are incapable of preventing nutrients from being leached, but the heavy application of manure during decades has raised the nutrient level. For example, the phosphorus level is quite high compared with most Ghanaian soils and so is $p \mathrm{H}$ (Soil Research Institute).

\section{The shallot farming system}

The history of land use system in Keta

In former days, as long back as historical evidences allow, the study area has been inhabited. People settled at the sand barriers and on the Keta sand spit while the marsh area remained uninhabited because of seasonal flooding. Formerly, fishing was the most important activity for the people, but they were also part time farmers growing a few vegetables for domestic consumption. According to Ocloo (1996), a Danish doctor and biologist, Isert, noted in 1788: "towards the sea the inhabitants (of Anloga) had many garden plots where they planted mainly plantain, bananas, yams and sugarcane. I had not seen sugarcane in Africa until then. The matured canes were more than the height of a man and just as thick as those in the West Indies". This economical system functioned very well for a long time, but at the end of the 19th century, coconut production had been introduced and began to play an important role as a cash crop, generating income for the society. But in the 1930s due to the world economic recession, the collapse of the coconut production by the Cape St Paul disease, and the rapidly increasing population forced the people to give up the old agricultural systems and developed intensive horticulture on the sand spit. The main crop became shallots, with pepper, okro and tomatoes as the main intercrop. It is a cash crop system where the products are sold for consumption in the bigger towns like the capital, Accra. Therefore, the crops are grown with a substantial input of manure, which has to be brought from outside. Furthermore, the whole system is based on irrigation to maintain a stable production in the dry periods and, hence, throughout the year.

\section{The farmland}

The farming is carried out on the Keta soil series and only on the Keta sand spit where a thin freshwater lens has developed at shallow depth. The presence of this freshwater lens is mandatory for the farming system because irrigation plays a central role. The farming is carried out on man-made sand beds located in areas with easily accessible shallow groundwater. They are, therefore, found in the depressions on the seaside of the main road (Fig. 1), or stretching from the main road towards the lagoon. The sand bed closest to the marsh area is artificially made. Sand from the spit has been taken by the farmers and deposited on the marsh surface, building up a $0.5-1 \mathrm{~m}$ of sand layer which makes farming possible. Recently, some upland areas on the sand spit have been included in the farming system after electric driven ground water pumping systems have been introduced. Fig. 3 shows a cross section of the sand spit indicating the fresh water lens and sand bed areas for shallot farming.

West African Journal of Applied Ecology - Volume 13 


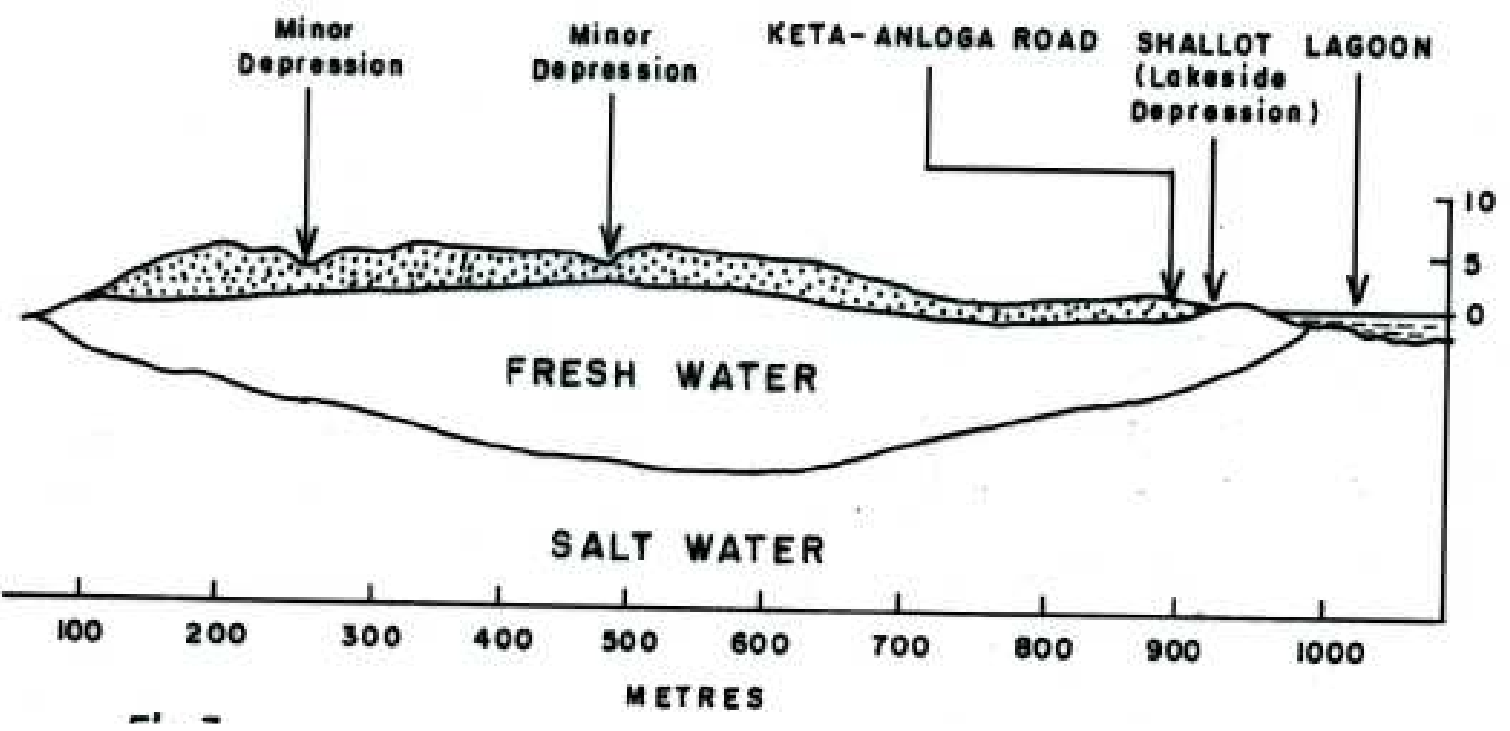

Fig. 3. A cross section of the Keta sand spit indicating the location of the shallot beds and the fresh water lens

The depressions range in width from few metres to more than a hundred metres and stretch from less than hundred metres to many kilometres. They are mainly located from Vui, Dzelukorpe through Anloga to Anyanui (Fig. 1). With the exception of the large coastal depression, the rest are relatively small in size. Fig. 4 shows the location of depressions at a part of the Keta sand spit from Anloga to east of Woe. Some of the depressions at Anloga were under cultivation as early as in the 18th century, mainly for local consumption.

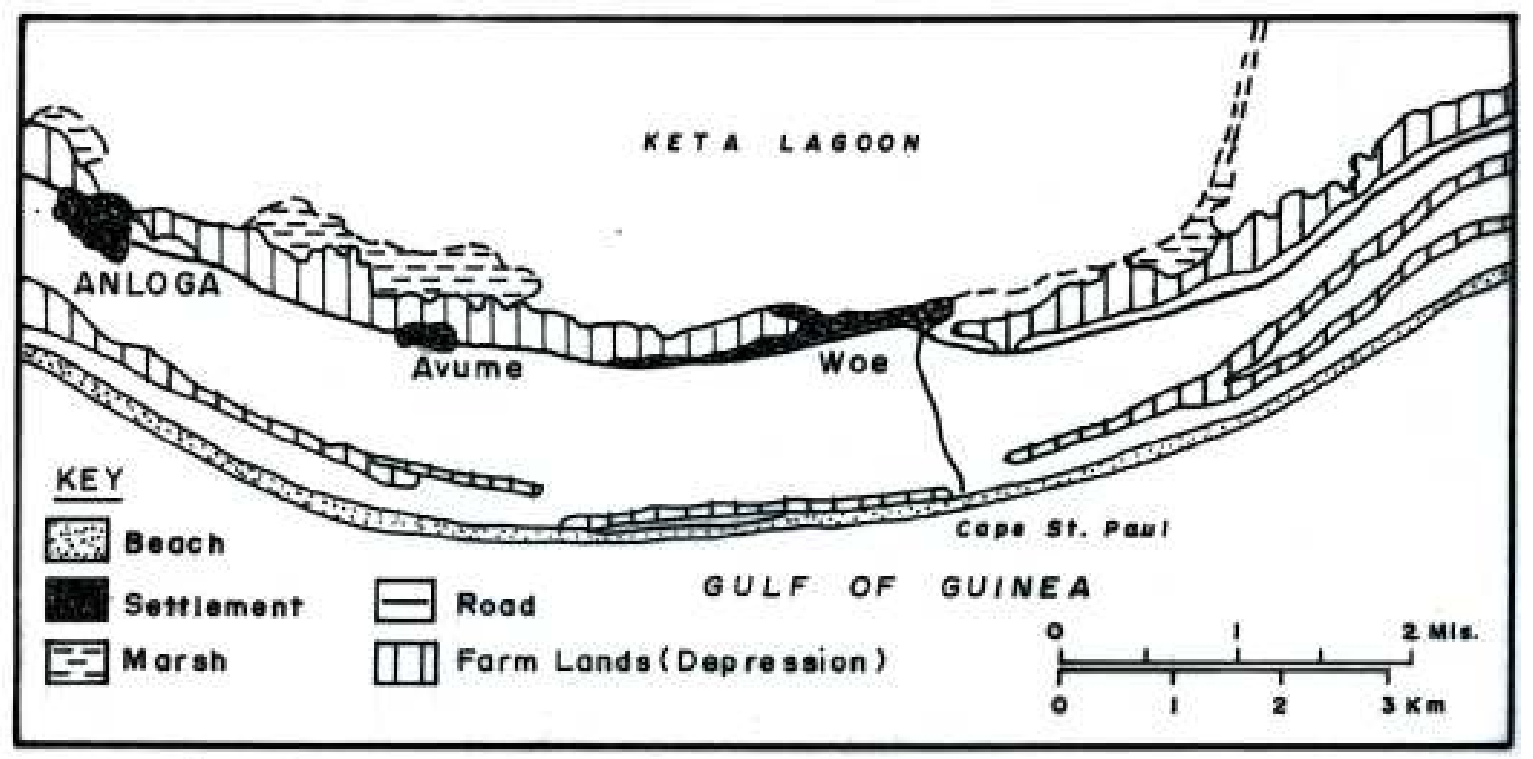

Fig. 4. The location of depressions at a part of the Keta sand spit

West African Journal of Applied Ecology - Volume 13 
There are two major depressions where the shallot horticultural system is practised. The depression on the seaside stretches from Woe through Avume and Anloga to the fresh water pond of Bloluito. This cluster is in three major parts. The largest section extends from Avume to the fresh water lagoon of Bloluito at the Western end of Anloga, the smaller section of Abutia extends from Avume to Cape St Paul. The second major cluster of depressions is the Woe Anloga-Wuti lagoon side depressions. It is in two contiguous parts separated by the Anloga town centre. The eastern part of it is from Woe to Anloga and the western cluster is from Wuti to Atisekorpe.

Facing the lagoon at the border to the marshy area, sand beds have been built on the marshy deposits using sand from the sand spit. Near the main road the beds are still on the sand spit but further apart a sand layer of about $1 \mathrm{~m}$ depth has been built up in some places on the marsh surfaces and the sand bed area stretches more than $1 \mathrm{~km}$ out over the marsh area. Near the main road the ground water is still fresh and well watering is possible, but further away it becomes brackish and farming can only take place in the rainy season of April through June. The farm area has increased during the 20th century and now covers about 3000 ha.

\section{Land preparation}

The preparation of the farm beds is dictated by the nearness of the water table to the surface. Because of the high water table of the area, the farm beds are raised to about $10-15 \mathrm{~cm}$ above ground level (Fig. 5). This is to ensure that the root zone of the plants cultivated is not affected by water logging conditions. Since the soils are made up of mainly loose sands, the sides of the beds are protected by lining them with maize stalks or by a local grass Paspalum vaginatum. This prevents the beds from levelling up. The beds are narrow, varying in width from 1.5 to $2 \mathrm{~m}$ and in length 10 to $15 \mathrm{~m}$, and are separated from one another by narrow channels which serve as foot paths and drainage controls, as the channels ensure that excess water is quickly drained out.

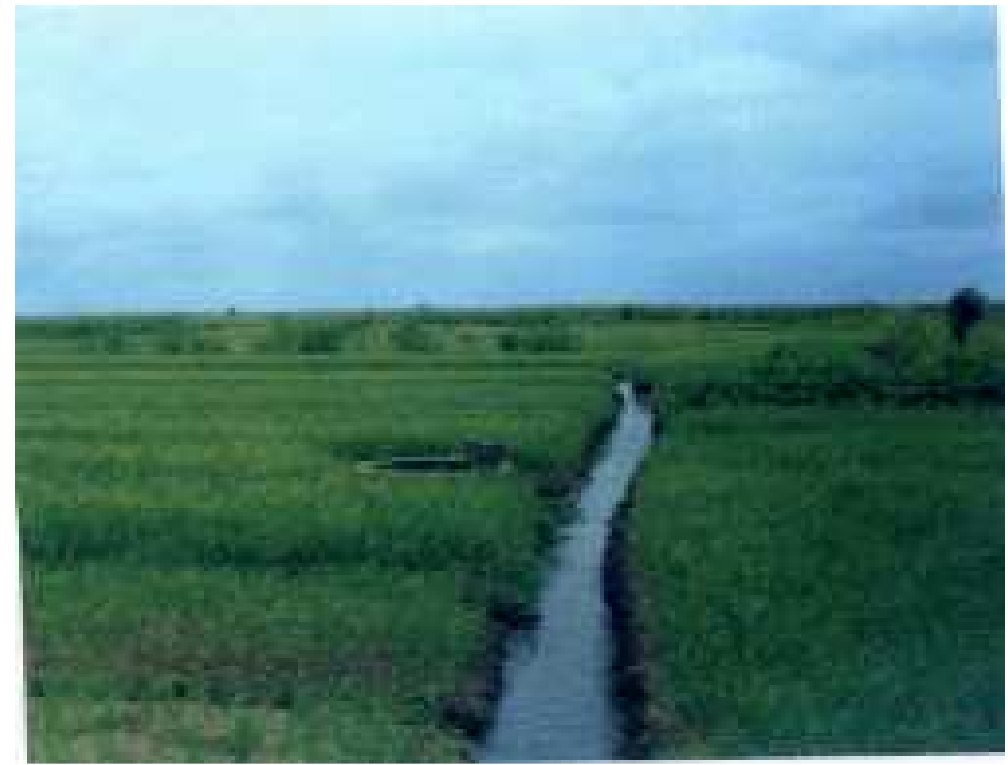

Fig. 5a) Shallot beds showing excess water collected in between beds 


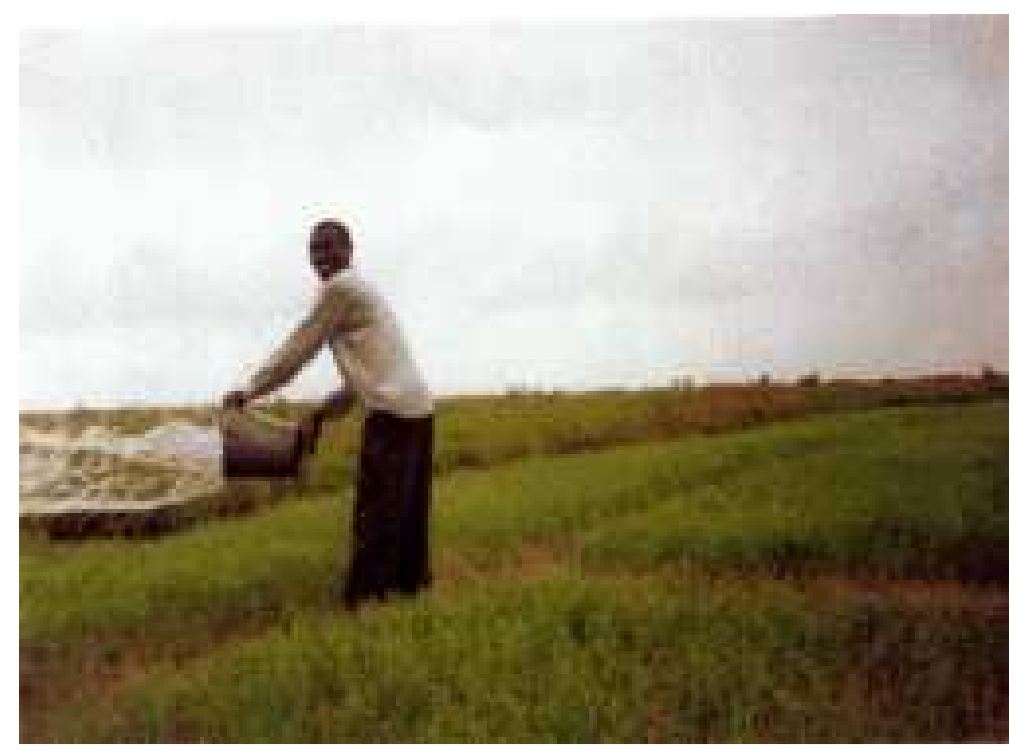

b) Irrigation by means of buckets

Crop

Crops have been selected to suit the physical environment, and all the important crops have a maturity period of 2-3 months. Shallot is the major crop around which the other crops revolve. Three major farming seasons are observed and the shallot is the first crop to be planted. Here, it is the bulbs that are planted because the high temperature throughout the year does not favour seed production. To be able to bear seeds shallot would need at least 6 weeks of "chilly" conditions after attaining a certain minimum size (Ocloo, 1996). This condition is not found in the study area, and the bulbs for planting are imported from the mountainous areas in the neighbouring country, Republic of Togo. The bulbs are planted by pushing them into the soil with a planting distance of about $10 \mathrm{~cm}$, and the weight of the bulbs used for planting is about $0.2 \mathrm{~kg}$ per $\mathrm{m}^{2}$.

Three weeks after planting, other crops like pepper, Capsicum annuum, okro Hibiscus esculentus L., and tomatoes, Lycopersicon esculentum Mill, are planted in between the shallots. Two months after the planting of the shallot, they are harvested, leaving the other crops to take over. The shallot yield is about 2-3 kg per $\mathrm{m}^{2}$ or about $10-15$ times in return. Table 2 shows that the yields vary from season to season and it is, on the average, lowest in the dry season. Diseases and bad seed bulbs might also decrease the yields in some particular seasons. The intercrops are harvested later than the shallots making way for the beginning of another planting season. There is, therefore, a continuous cultivation throughout the year with no fallow periods. In some cases maize or cassava is cropped for domestic consumption. In this case it is possible to harvest six times a year, with tomato, okro and pepper.

TABLE 2

Shallot average yields from nine sand beds for a 4-year period 1998-2001. The yields are in $\mathrm{kg} / \mathrm{m}^{2}$

$\begin{array}{llcl}\text { Year } & \text { Jan.-Mar. } & \text { Apr.-Jun. } & \text { Sept.-Nov } \\ 1998 & 1.9 & 3.2 & 2.3 \\ 1999 & 2.4 & 2.3 & \text { no data } \\ 2000 & 1.6 & 3.3 & 0 \\ 2001 & 2.5 & 3.4 & 3.0 \\ \text { Average } & 2.1 & 3.1 & -\end{array}$

West African Journal of Applied Ecology - Volume 13 


\section{Irrigation}

Irrigation forms an important part of the agricultural system. In tropical areas with annual rainfall of less than $900 \mathrm{~mm}$, cultivation of crops on sandy soils throughout the year is impossible without irrigation. In the dry season of January-February-March irrigation is carried out throughout the season. This period is extremely dry (Fig. 2), and the average precipitation in January and February does rarely exceed 25 $\mathrm{mm}$. As the potential evapotranspiration is about $4-5 \mathrm{~mm}$ per day, the precipitation should be more than $200 \mathrm{~mm}$ in these two months to support plant growth. Tube wells have been sunk among the beds and water is drawn using buckets to irrigate the crops (Fig. 5). The density of wells in the farmland is high; about one well per five beds, and, presently, the number of wells is estimated to be several thousands. The wells are about 1-2 m deep, and the water level is normally within $1 \mathrm{~m}$ from the surface.

In some years, wells might dry up in the dry season if the minor rainy season had failed. The quality of the well water is normally good and the electrical conductivity is in most places below $2 \mathrm{dS} / \mathrm{m}$, which is the critical tolerance level for many not salt tolerant vegetables, but in some places higher EC-values are found reducing the yields significantly or completely spoiling the harvest. Table 3 shows the EC of the well water in year 2001 supplying irrigation water to the nine sand beds. The values demonstrate some variation over the year, and critical high values are especially found in January 2001 where half of the wells showed values above $2 \mathrm{dS} / \mathrm{m}$. The irrigation water with high salt concentrations might lead to high salt concentrations in the soil and, thereby, decreasing yields.

TABLE 3

The electric conductivity $(\mathrm{dS} / \mathrm{m})$ during year 2001 for eight wells used in irrigating the nine shallot beds

$\begin{array}{llllllllllll}\text { Jan } & \text { Feb } & \text { Mar } & \text { Apr } & \text { May } & \text { Jun } & \text { Jul } & \text { Aug } & \text { Sep } & \text { Oct } & \text { Nov } & \text { Dec } \\ 0.8 & 0.8 & 0.8 & 1.2 & 1.2 & 1.0 & 0.9 & 0.9 & 0.8 & 0.4 & 0.7 & 0.8 \\ 0.6 & 0.7 & 0.7 & 2.2 & 1.0 & 0.6 & 0.7 & 0.6 & 0.5 & 0.4 & 0.6 & 0.6 \\ 2.5 & 1.4 & 1.4 & 1.4 & 1.8 & 1.5 & 1.3 & 1.3 & 1.3 & 0.7 & 1.1 & 1.3 \\ 2.4 & 1.2 & 1.2 & 1.1 & 1.1 & 1.1 & 1.5 & 1.0 & 1.2 & 0.8 & 1.4 & 0.8 \\ 0.7 & 0.7 & 0.7 & 1.4 & 1.4 & 1.4 & 1.1 & 1.2 & 0.9 & 0.5 & 0.7 & 0.7 \\ 2.3 & 1.0 & 1.0 & 1.0 & 1.3 & 0.9 & 1.2 & 1.5 & 1.3 & 0.8 & 1.4 & 1.4 \\ 2.5 & 1.5 & 1.6 & 2.0 & 1.9 & 1.6 & 2.1 & 1.6 & 1.3 & 0.8 & 1.7 & 1.6 \\ 0.9 & 1.0 & 0.9 & 1.1 & 1.0 & 0.7 & 0.9 & 1.0 & 0.9 & 0.5 & 0.9 & 0.9\end{array}$

In 2001 the electrical conductivity (salt concentration) was measured on soil samples at harvest from eight out of the nine farm beds (Table 3). In the dry season (January-March) EC was $1.3 \mathrm{dS} / \mathrm{m}$, in the wet season (April-June) $0.3 \mathrm{dS} / \mathrm{m}$ and in the season with irrigation (September-November) $0.7 \mathrm{dS} / \mathrm{m}$. This partially explains the low yields in the dry season. The beds are irrigated a day before planting and 5 days after planting. Irrigation is then done twice a day, morning and evening, until maturity. There is less irrigation during the May-July and September-November seasons since those are the two rainy seasons, but even in the major rainy season it is necessary to irrigate, when there is a break in rainfall.

Within the last decade, electric groundwater pumping technology has been introduced in the area, and fields outside the traditional areas on the sand spit are now turned into farmland. Here shallots, pepper, okro and tomatoes are grown based on sprinkler irrigation. This type of irrigation is labour saving, but the water consumption may be problematic, because much of the irrigation water evaporate before it reaches the ground. This is especially the case when the irrigation takes place during the daytime.

Manuring

Manuring forms a very important aspect of the system, because the nutrient cycle is truncated when the crop is harvested and sold. Furthermore, as discussed earlier, the soils are naturally very poor in plant nutrients. In the past, bat droppings were used as manure and, up to the 1960's, dry fish was also used as manure but had become too expensive and unavailable due to competition from poultry feed manufacturers. Cow dung and poultry droppings are now the organic manures used in the area. Cow dung West African Journal of Applied Ecology - Volume 13 
is normally applied before planting and in every growing season about $1.3 \mathrm{~kg}$ of cow dung per square meter is used. There are two types of cow dung. The cow dung obtained from kraals in the environs of the Keta Lagoon and the cow dung obtained from cattle fed on poor quality grasses of the Accra Plains. The former tends to be richer in nutrients than cow dung from the Accra Plains.

Cow dung is used during the three major planting seasons of the year but has the problem of renewing the weed seed bank. The poultry droppings are preferred by the farmers for use in the rainy season as the rains help to reduce the heat generated at the early stages of application. The cow dung and the other organic fertilizers, in addition to improving the soil fertility, also help to improve the soil structure and water holding capacity. Since the 1970s, chemical fertilizers have been introduced. Some farmers still apply NPK and urea but the use of chemical fertilizers is gradually declining because of the removal of government subsides and the resultant high cost.

\section{Weed and pest control}

Weed control continues to be a problem. One would have thought that the several decades of weed picking would have reduced the weed menace, but the use of cow dung brings weed seeds that maintain the seed bank at high levels. Weeding after planting is done by hand picking, and this may be done for about three to four times during the season. Pest control is achieved primarily by enforcing rules governing the planting time for each season. No farmer is allowed to plant a month after the commencement of the planting season. Offenders are punished. The enforcement of this regulation reduces the multiplication and spread of fleas that damage the shallot. Chemical pesticides are now available, but their use is very limited because of rising cost.

\section{Sustainability of the shallot system}

The shallot agricultural system shows an excellent adaptation to a harsh and dynamic environment that is not suitable for traditional crop production. The system developed is a horticulture system requiring a high input of nutrients and adequate water supply from a local aquifer. Because of the constantly growing population and socio-economical factors, the production system has been intensified and new fields have been established, putting pressure on the environment and questioning the sustainability of the shallot system in the future. The major problems the system is facing today are the accommodation of a growing population, land fragmentation, the possible depletion of the aquifer used for irrigation, pollution of the aquifer by nutrients and pesticides, the high cost of production, and competition by imported onions from northern Ghana and foreign countries.

\section{Increasing population and land fragmen-tation}

The population has been constantly growing during the last century and it doubles within 20 years. It is not possible to accommodate this population by increasing the farmland because all farmland towards the lagoon is already farmed, and widening the depression on the sea side of the main road cannot increase the farm land area significantly. Thus, in the future, people have to develop alternative income generating activities or leave the area and move to more economically expanding areas, like the bigger towns. The land tenure system in use also poses a threat to the sustainability (Nukunya, 1972; Benneh, 1972). Land is shared among children after the death of their father, and this had continued for over several generations. The result is that many farmers now own farmlands that are less than 0.02 ha and, at times, this may even be scattered in two or more parts. The land fragmentation had resulted in farmers owning lands that are uneconomic. Land fragmentation is, therefore, a threat to sustainability and it is hoped people will sell or lease their holdings to others in order to be able to get bigger farms, which will be economically viable.

\section{The aquifer}

Since 1980 total annual rainfall had remained below $900 \mathrm{~mm}$ per annum, with 10 of those years remaining below $600 \mathrm{~mm}$ (ACRES, 1992). The low, rainfall had negatively affected the rate of recharge of the aquifer, and the effect of this had been crop failures in those years where the wells have not been West African Journal of Applied Ecology - Volume 13 
able to supply the farmer with enough water. The ever-growing population has forced the development and establishment of a farming system outside the depressions based on sprinkler irrigation. This system uses more water than the hand and bucket irrigation system, especially when irrigation is done in the middle of the day when evapotranspiration is higher. It is feared that this system, if not properly done, will quickly help in the depletion of the aquifer. In addition to the increasing need of irrigation water, the rapidly growing population increases the domestic use of water, which is also taken from the aquifer.

The volume of the freshwater aquifer overlying a saltwater lens is not known, but drilling at one of the sprinkler-irrigated fields in the central part of the spit revealed that the freshwater lens was only few metres deep. Similar conclusions were made by Armah et al. (1997) based on observations from two wells at a tree seedling nursery at Anloga. As no monitoring program has been set up to follow the development in the size of the freshwater lens, it is not clear whether the natural recharge system through the excess of water in the rainy season is still able to support the current level of water exploitation of the freshwater lens. Even if the precipitation surplus in the rainy season can support the recharge of the aquifer today, it is a question of whether the increasing use of pump irrigation and sprinkler irrigation in the future can be supported, or a depletion of the aquifer will take place. If so, salt water intrusion into the freshwater lens will occur with serious consequences for the farming system and for the domestic use.

\section{Pollution of the aquifer with nutrients and pesticides}

The heavy manuring of the sand beds increases leaching of nutrients which pollute the aquifer. The salt concentration in the uppermost $10 \mathrm{~cm}$ of the soil is very high just after manuring, and investigation of the drainage water running between the sand beds after heavy showers has shown EC values above $3 \mathrm{dS} / \mathrm{m}$. As the distance to the freshwater lens is short a lot of nutrient is leached to the aquifer, from where some of them later are returned to the sand beds by hand and bucket irrigation. A comparison of the EC of rain water and well water from the nine experimental plots shows that EC of the rain water is about $0.04 \mathrm{dS} / \mathrm{m}$ while in the wells it varies between 0.4 and $2 \mathrm{dS} / \mathrm{m}$, indicating leaching of nutrients from the soil. Chemical analysis of the aquifer is few and it is not possible to give any average values, e.g. $\mathrm{NO}_{3}$ concentration, but the deter-mination of the nitrate content in the well water from the nine experimental plots indicates that the nitrate concentration in some places is above the limits set up by WHO for drinking water (>50 mg/l). The nutrient content in the aquifer will not decrease in the years to come; it is likely to increase, as more lands will be farmed outside the depressions.

Pest control is achieved primarily by enforcing rules governing the planting time for each season. These rules are rigidly enforced on the lagoon side farms but not on the sea side farms. This might break down the ecological based pest control and force the farmers to use pesticides. In previous times the pesticides were put into the wells and then by hand and bucket irrigation brought to the sand bed. This is not done anymore, but even though the use of pesticides today is done in a more correct way, the continuous use of pesticides is questionable as the retention capacity of the soil is low and the depth to the aquifer is shallow. Thus, an increasing use of pesticides is a threat to the population, as it makes the water not drinkable.

Socio-economic constraints

The farming system is highly dependent on nutrient inputs, but they have, during the last two decades, become very expensive. Cow dung and poultry droppings are obtained in the Sege area, about $100 \mathrm{~km}$ from the farms. Poultry droppings are also obtained from the Tema area, about $150 \mathrm{~km}$ away. With rapid fuel price increases during the last 20 years, production cost is wiping out any profits that the farmer makes. The high production cost is making shallot production to be more expensive when compared with onions produced in Bawku in northern Ghana and imported ones from the Republic of Niger and Europe.

Therefore, many farmers are now phasing out the shallots and developing a crop rotation system based on pepper, okro and tomato, where the economic input of seed and manure is lower and the market condition better, giving an adequate economic return. Poor farmers give up horticulture because of lack of

West African Journal of Applied Ecology - Volume 13 
money for seed and manure and grow maize or cassava on the beds for domestic consumption. If the economic return of growing shallots is not increased in future, shallot farming will turn into a pepperokro-tomato horticulture system.

\section{Conclusion}

It would seem as if the shallot system is under threat and may not be sustained for economic, and environmental reasons. If the economic returns by shallots production are not increasing so it can compete with other produce, the system will turn into a pepper-okro-tomato horticultural system, as it is already happening. But in the future environmental problems, like depletion of the fresh water aquifer and pollution of the aquifer by pesticides and nutrients, might change the farming system drastically. Quota on water used for irrigation might be introduced like limits for the use of manure, as seen in other countries. This will change the agricultural system drastically, and it may be a question of whether it can survive as a horticulture system in its present form.

\section{References}

ACRES International Ltd (1992) Southeast Ghana Agricultural Development Project. Preliminary study. CIDA Project No. E4936-K03980. Canadian International Development Agency and Republic of Ghana, Ministry of Agriculture, Accra.

Ahn P. M. (1970). West African Soils. Oxford University Press. London, U.K.

Armah A. K., Awumbila M., Clark S., Szietror A., Foster-Smith R., Porter R. and Young E. M. (1997). Coping responses and strategies in the coastal zone of south-eastern Ghana: A case study in the Anloga area. In The Coastal Zone of West Africa - Problems and Management. Proceeding of an international seminar 23-28 March 1996, Accra, Ghana. (S. M. Evans, C. J. Vanderpuye and A. K. Armah, ed.), pp. 17-27. Penshaw Press, UK.

Anon. (1993). Ramsar library: The directory of wetlands of international importance, 4th edn. www.ghanaweb.com

Asiamah R. D. (1995). Soils of the Ho-Keta Plains, Volta Region, Ghana. Memoir No.10. Soil Research Institute. Kumasi, Ghana.

Benneh G. (1972). Land Tenure and Sabala Farming System in the Anlo Area of Ghana. A case study. Technical Publication series. No. 3. ISSER, Legon.

Brammer H. (1967). Soils of the Accra Plains. Memoirs No. 3. Soil Research. Institute. Kumasi, Ghana.

Christensen E. and Awadzi T. W. (2000). Water balance in the moist semideciduous forest zone in Ghana. West Afr. J. appl. Ecol. 1: 11-22

Dickson K. B. and Benneh G. (1995). A new Geography of Ghana, 3rd edn. Longmans Book Company.

ISSS/ISRIC/FAO (1998). World References Base for Soil Resources. World Soil Research Report 84. FAO, Rome.

Jeppesen H. (1971). Shallot cultivation near Keta (in Danish). Naturens Verd. 1: 25-31

Ocloo C. F. (1996). The Anlo Shallot Revolution 1930s-1992. Norwegian University of Science and Technology, Department of History, Trondheim.

Nukunya G. K. (1972). Land Tenure and Inheritance in Anloga. Technical Publication series No. 3. ISSER. Legon.

Purnell M. F. (1955). The Shallot Industry, Keta District. Technical Report No.16. A Report on the soil conditions with references to proposed dyke. Soil and Land-use Survey, Kumasi.

Soil Survey Staff (1998). Keys to Soil Taxonomy, 8th edn. USDA-NRCS, Washing ton, DC.

Sorensen T. H., Volund G., Armah A. K., Christensen C. Jensen L. B. and Pedersen J. T. (2003). Temporal and spatial variations in concentrations of sediment nutrients and carbon in the Keta Lagoon. Ghana. West Afr. J. appl. Ecol. 4: 91-105.

West African Journal of Applied Ecology - Volume 13 